\title{
NEUTER GENDER - A WAY TO INVOLUTION
}

\author{
Maria A. URECHE* \\ Constantin N. GHEORGHIU*
}

\begin{abstract}
The new type of gender ideology overrides the biological and psychological realities of the person, desiring reconstruction of a new man, androgynous type, neuter. This neomarxist doctrine is a direct attack on the family and child, creating an atmosphere of promiscuity and confusion through the disappearance of real biological gender. By ideological education (for example sex education) the child is misguided to experience sexual identities. These fake psychological reconstructions of the person are an attack on the rights of its real identity. Man was created by God, man and woman, without the existence in the Holy Scripture of a third gender, neutral. Imposing this ideology against the integrity of the person has only one seam, the antichrist, the denial of man as a creature of God who is tending towards deification.
\end{abstract}

Keywords: gender, trans-sexualism, family, androgynous, bio-psychological deconstruction

\section{Introduction}

Gender ideology tends toward psycho-social deconstruction of the individual as man and woman, wife and husband, father and mother. Through the new cultural ideologies, these identities toward which the individual tends to fulfill, are not only altered, but eliminated from the sphere of society, promoting the postmodern man as an egocentric god, totally released from the tyranny of nature anf biology, an active member of these socio-cultural revolutions. Thus, the person is reduced to individual selfishness, hedonism and consumerism, not needing

* PhD, Assistant Professor, Faculty of Law and Social Sciences, "1 Decembrie 1918" University, Alba Iulia, Romania.

* Professor, High school, Gura Humorului, Suceava, Romania. 
dedication, love and sacrifice for others. During his lifetime, the postmodern man does not seek to develop the uniqueness of the person through communion with others, he no longer needs the freedom of speech for communion with the Logos, being considered an object of consumption that undergoes rebranding and refresh in the course of the new socio-cultural directions.

New social inventions intend to create a family without landmark in God and stability through love and koinonia, creating false oppressions, injustices, violence and social revolutions. Within the family, the husband and the wife are stigmatized as an aggressor and victim, the woman being stigmatized as being oppressed by her husband, and the motherhood being promoted as social inequality, and thus women being urged to practice abortion as a form of release.

This subversive ideology promises to give women rights, wants to free them from maternal feelings (maternity is considered a myth appeared in a certain period of history), from the husband (who afflicts her in the form of the patriarchate) and from the child (the desire to legalize the abortion), but in reality, the target consists in the disintegration of the family, motivating that inside it, would be produced the first social inequalities, the woman having only a slave posture. Through this, it is proposed replacing the family with a cohabitation by contract. The child is transformed into a citizen with rights, educated only by the state and no longer knows the values of the family and the mysterious meaning of love, faith, unity, obedience, respect, sacrifice.

In education and the choice of moral values and religion, parents can no longer intervene, they are presented to the child by gender ideology as parent 1 and parent 2, increasing the ambiguity regarding the status and role of parents within the family. The term Adultismus was recently introduced into German education, being considered as the unequal relationship between adults and children, who are often discriminated and oppressed by adults ${ }^{1}$. Contemporary children from industrialized Western society no longer seek identity patterns among their parents or other persons/personalities, no longer seeking interaction with them, technology becoming a false substitute for the person. Since

1 Martina WinkLer, Kindheit als Kategorie. Adultismus im Zusammenspiel mit anderen Herrschaftsverhältnissen, Bremen, 2015, p. 6. 
childhood, they form an e-identity. or a fictional identity, more and more specialists talking about an end of childhood ${ }^{2}$.

The new gender culture tends to destroy the rites of passage, the human and astral ages, the rhythms of nature, the sacro-prophan dichotomy (which is demitologized), no promoted paradigmatic models, and the rations of created things that confirm the life of the community and the person's sense and harmony are annihilated ${ }^{3}$.

\section{The concept of gender}

The concept of gender is a synthetic one, having other shades and with a totally different meaning than the ones presented in dictionaries or by the ideologues of this movement. There is no real definition of this socio-political ideology, the language used by those who call this movement a cultural and revolutionary one is to use terms with positive connotations to value something other than what it specifies. They use an ambiguous language, creating the impression that they are fighting for women's rights, but the purpose seems to be another. It is certain that family and maternity are seen as an obstacle to the successful completion of the revolutionary program ${ }^{4}$.

The first who used the term gender with a different meaning of the word was the American sexologist John Money (1921-2006), who in the article: "Hermaphroditism, gender and precocity in hyperadrenocorticism: Psychologic findings" presented the concept of "gender roles", being used to describe the behavior of a man or woman not belonging to their sexual categories, another role played by them in society ${ }^{5}$. Later, following the experiments at the John Hopkins Hospital, he noticed that the child's sexual orientations could be alterated, manipulated since childhood, Money claiming that they were not hereditary. Thus, it was concluded that the gender roles assumed by men

${ }^{2}$ Pascal HonISCH , Kindsein 2.0: Die Konstruktion von Kidults anhand der Phänomene des EGaming und Hello-Kitty-Konsums, Hamburg, 2014, p. 9-11.

${ }^{3}$ Arnold van GENNEP, Rites of passage, translated by Lucia Berdan and Nora Vasilescu, Iaşi, Polirom, 1996, p. 14-39.

${ }^{4}$ Gabriele KuBY, Gender, A new ideology destroys the family, translated by Alexandru Ş. Bologa, Iaşi, Sapientia Publishing House, 2014, p. 11-12.

${ }^{5}$ Laura PaLAZZAni, Gender in Philosophy and Law, London, Springer, 2012, p. 2. 
or women are the expression of the gender identity ${ }^{6}$. Money defines gender as the sum of behaviors of a person who reveals that he is a man or a woman and not a biological $\operatorname{sex}^{7}$ and gender identity as the identical character, unity, persistence, individuality of a man or woman, or both, and private experimentation of the role gender ${ }^{8}$. These studies, besides being challenged and abolished over the years, continue to be sources of study for both gender theorists and feminist organizations.

Terminology was taken over by psychoanalyst R. J. Stoller (19241991) who, in 1964, at International Psycho-Analitical Congress that took place at Stockholm, distinguished between sex and gender, stating that gender represents social relations, culture, the system, and sex is biological. Thus, gender roles represent cultural stereotypes ${ }^{9}$. He creates the term gender identity to reflect a person's fundamental feeling about belonging to a gender and becoming aware of his or her own identity. According to Money's research on changing children's concepts from early years, gender roles can be changed from the very beginning of childhood ${ }^{10}$. Gender identity begins with the awareness that it belongs to a sex and the role of gender is the person's behavior in society with other people. Thus, the gender role is the public expression of gender identity.

Other ideologues, such as John H. Gagnon (1931-2016) and William Simon (1930-2000) introduced the term sexual identity to characterize the individual as a sexual agent, claiming that a person's sex is a result of learning, indoctrination and experimentation ${ }^{11}$.

Ideological exponents and "human rights experts" met in Yogyakarta, Indonesia, and defined gender identity as follows:

"Gender identity is understood to refer to the intimate and personal experience of each person's gender, which corresponds to or not to the sex given at birth, including the personal consciousness of the body

6 J. Money, P. TuCKer, Sexual Signatures. On being a Man or a Woman, London-Toronto, 1975 , p. 86.

${ }^{7}$ Laura PALAZZANI, op. cit., p. 3.

8 J. Money, Gay, Straight, and In-Between: The Sexology of Erotic Orientation, New York Oxford, Oxford University Press, 1988, p. 8-10.

${ }^{9}$ R. J. STOLLER, “Gender-role change in intersexed patients”, in JAMA, nr. 188/1964, p. 685.

${ }^{10}$ Ibidem.

11 John H. Gagnon, William Simon, Sexual conduct: the social origins of human sexuality, Chicago, Aldine, 1973, p. 21-33. 
(which may involve, it is freely consented, the modification of the body's appearances or medical functions, surgical or others methods) and other expressions of the genus, including clothes, speech, conduct"12. "The notion of sexual orientation refers to a person's ability to feel emotionally and sexually attracted to persons of the same sex and to have sexual relations with them"13.

This definition, does not exclude other sexual deviations (pedophilia, incest, polygamy $)^{14}$.

The World Health Organization defined gender as the result of socially constructed ideas about behavior, actions and roles that a particular sex performs.

The European Union Legislation: Austria, Germany (TSG-Gesetz über die Änderung der Vornamen und die Feststellungder Geschlechtszugehörigkeit in besonderen Fällen), Belgium (changing of 62 bis article from the Civil Code), Ireland, Italy, Spain (through the Law regarding changing of the sex in civil registration from 2007) Great Britain (The Gender recognition Act-2004) began to defend the rights of transgender people, through anti-discrimination laws and access to certain social services. In some of these states are granted the right to marry same-sex and the right to adopt children. In 2006, the European Parliament adopted a resolution against homophobia (B6-0025/2006), which continues to implent gender mainstreaming through education and legislation.

\section{Marxist Theory}

Karl Marx's Utopia (1818-1883) and Friedrich Engels (1820-1895) in a society without social classes in which all men are equal, could not have been accomplished unless two foundations of the person were destroyed: the belief in God and the family. In fact, Engels, in his book about the origin of the family: "Der Ursprung der Familie, des Privateigenthums und des Staats. Im anschluß an Lewis H. Morgans Forschungen" said the family does

12 Principles from Yogykarta, translated by Adrian R. Coman, Iustina Ionescu, Romaniţa Iordache and Mona Nicoară, s.1., 2009, note 2, p. 6.

${ }^{13}$ Gabriele KUBY, The global sexual revolution. The destroying of liberty in the name of liberty translated by Alexandru Ş. Bologa, Iaşi, Sapientia, 2014, p. 127.

${ }^{14}$ Ibidem. 
not release the individual to join the horde and polygamy. According to Engels, monogamous marriage is a form of woman's subjugation, here appearing the first contradiction of class and the first antagonism, the first class oppression, women being oppressed.

Engels argues that love between man and woman could only be possible within the oppressed class ${ }^{15}$ who did not own any property, claiming the release of the family ${ }^{16}$, the removal of private property and women's access to work, in order to create a single family as the economic unit of society ${ }^{17}$. This inequality and oppression was continued by Max Horkheimer (1895-1973) and other representatives of the school in Frankfurt who concluded that patriarchal authority within the family is an evil model for children ${ }^{18}$ because it reproduces human characters ${ }^{19}$, so, for the existence of a non-hierarchical and non-tribal society should be created a family in which there is no hierarchy ${ }^{20}$ and it can only be created by indoctrination and by promoting the ideology of tolerance.

The end of class struggle can only be achieved by destroying the family and abolishing hierarchies and relationships between men and women. This gender ideology is called by neo-marxist a revolution in revolution, the ultimate goal being not only the elimination of the family, but also the deconstruction of the woman, because her maternity could damage the capital market.

\section{Postmodern culture}

The source of gender ideology is the nihilist postmodern thinking, the cultural neo-marxism of the school in Frankfurt, and the influence of the writings of Sigmund Freud (1856-1939) and Friedrich Wilhelm Nietzsche (1844-1900), but also the French poststructuralist thinking with exponents such as: Jacques Derrida (1930-2004), Michel Foucault (19261984), Gilles Deleuze (1925-1995), Jean Baudrillord (1929-2007), Jean

\footnotetext{
${ }^{15}$ Friedrich Engels, Der Ursprung der Familie, des Privateigenthums und des Staats. Im anschluß an Lewis H. Morgans Forschungen, Hottingen-Zürich, 1884, p. 36-84.

16 Ibidem.

${ }^{17}$ Ibidem.

${ }^{18}$ Max HorkHEIMER, Studien über Autorität und Familie, Frankfurt, 1987, p. 49.

${ }^{19}$ Ibidem.

${ }^{20}$ Ibidem.
} 
François Lyotard (1924-1998) etc.

Postmodern thinking gives the state leverage for anti-criticism, anti-history, anti-cartesianism, anti-humanism. Being opposed to the Cartesian rationalism thath promised intellect-to-progress guidance, postmodernism theorists emphasize the emotional man, the body man based on emotions, sex and rewards. The postmodern man is more oriented towards the material element, causing an absence of the development of science and a lack of morality.

Another feature is the rejection of the foundation of the classical culture of truth, the denial of the correct understanding of the truth of the ration of the freedom of faith in God, the unity of the family and the uniqueness of the person.

Postmodernism teaches the death of the fundamental values of classical human thinking, considering myths as the reality of God's existence and cataloguing fundamentalism of the religious man, the woman who devotes herself to the family, the moral education of the family, abstinence etc.

The postmodern man follows only that truth, only the good that is useful to his own benefit, which prolongs his pleasure, promoting hedonism and consumerism as a lifestyle. The new man must be tolerant, open to strangers and to the new, unprejudiced and demystified.

One of the key concepts of postmodern ideologists is to promote gender ideology and change fundamental social structures: family, school, society, child, maternity, work, migration, nationality, God, etc.

\section{The Radical Feminism}

Another ideological source is the radical feminist movement that is being promoted today in all media sources as a cultural model, a modus vivendi for the new generation.

Feminism is influenced by the Marxist theory that claimed that the first class struggle was taken in the family ${ }^{21}$.

Representatives of the feminist trend demand the elimination of the hierarchical structures in society, the emphasis on women's role in work and the denial of man's role within the family, the woman doing a triple

${ }^{21}$ Friedrich ENGELS, op. cit., p. 36-84. 
work: reproducing (giving birth to children), producing (preserving a job), and social reproduction (by raising children). Because women's oppression no longer takes place, feminists suggest that women should have the right to abortion and children should be raised in creches by the state $^{22}$.

Thus, feminists want to eliminate all the differences between man and woman, and the roles they have in the family, claiming that these roles can be interchangeable. They deny the biopsychological realit,y claiming it is a myth. They promote all deviant sexual behaviors that are considered normal and which in the past the culture considered immoral.

Some representatives of this revolutionary movement of eliberating woman from man's oppression go further, proposing hermaphroditism as the full release of man from the prison of the biological.

This radical movement fights against maternal love, the woman's ability to give birth to children, which feminists consider one of the biological injustices. The radical feminist movement calls for the universal promotion of sexual freedom, provoked abortion, contraception, growth and education of children in creches by the state in order for the woman to be free to enter as quickly as possible the workforce.

The promotion of the lawfulness of abortion and concubinage, of artificial equality as a result of social engineering, restricts women's rights to free choice and puts women in a single way of choice, the correctness of postmodern culture. At the Fourth United Nations Conference on Women, held in Beijing in 1995, was presented an action program that was adopted by 191 countries and which proposes equal work for women, but which does not address the family, marriage, children, promoting abortion on a large scale, the ideal being the woman employed and without a family.

\section{Man and woman, the crown of divine creation}

Man's creation by God was accomplished in His likeness by giving him His attributes; God merged the material world with the spiritual one

${ }^{22}$ Sara Delamont, Feminist Sociology, London, Sage Publications, 2003, p. 105-110. 
as a gift for all creation. As the crown of creation, man has the duty to sanctify all creation through love, sacrifice and communion between man and woman. The Creator did not create them for antinomy, but for harmony, for both to be a body.

Adam and Eve were personal creatures who were in a free and conscious communion, and were permanently with God, both oriented towards holiness. Even King Solomon said: "God created man immortal, made to be a likeness to Himself." (Wisdom of Solomon 3:23).

Man is not perceived as a contemporary philosophical thought to be a measure of all things, but is created to sanctify and direct creation to God. Man is called to become God by grace. This mysterious connection is noticed not only by the Holy Fathers, but also by pagan philosophers. Thus, Plato affirms that man is like a plant with roots directed to the sky from where he received his soul, being related to divinity ${ }^{23}$.

God did not create the creature to live in isolation and selfishness but, from the beginning, by divine counsel, created man, man and woman, embodying the good of His nature in the two, living in a personal communion to which they have the freedom to answer ${ }^{24}$ (Mark 10:6; Mathew 19:4)

"And God said: "Let's make man in the likeness of ours, that may possess the fish of the sea, and the fowls of the air, and the beasts of the earth, and all the beasts that go down upon the earth, and all the earth. And God made man in his image, in the likeness of God he did it". (Genesis 1:26-28)

And the Lord God said: "It is not good for the man to be alone; to make him a suitable helper for him. And the Lord God, who made of the earth all the beasts of the field and all the birds of the sky, brought them to Adam to see how he will call them; so that all living being should be called as Adam. And Adam named all the animals, and all the birds of the air, and all the wild beasts; but for Adam there was no help for him. Then the Lord God brought Adam to sleep; and if he fell asleep, he took one of his ribs and filled his place with flesh. And the coast taken out of Adam made the Lord God a woman and brought it to Adam. And Adam said:

${ }^{23}$ Platon, Timaios 90a, in Works VII, translated by Petru Creția and Cătălin Partenie, Bucureşti, Ştiinţifică Publishing House, 1993, p. 212.

${ }^{24}$ Saint Gregory of Nyssa, Homilies at Hapiness, translated by Sandu Stoica, Bucureşti, Anastasia, 1999, p. 88-89. 
This is bone of my bones, and flesh of my flesh; she shall be called a woman, because she is taken from her husband. Therefor shall man leave his father and his mother, and will be with his woman, and will be both a body." (Genesis, 2:18-24).

The purpose of Creation was for the multiplication of the human race, "Grow and multiply and fill the whole Earth and obey it ..." (Genesis 2:24) "For this man will leave his father and his mother, and they will both be a body. That is why they are not two, but a body. So, what God brought together, man not to separate" (Matthew 19,5-6).

The importance of the woman as equal with man and cohabiting is evidenced by St. Cyril of Alexandria: "Then, taking out a coast of Adam, he shapes the woman to give birth and to live together as one of the same nation and live together in simplicity ${ }^{25}$, but also to have help from the same body and equal in honor ${ }^{26}$.

Apostle Peter teaches: "You men also live wisely with your wives as weaker beings, and make them honorable, as some who, together with you, are heirs of the grace of life, so that your prayers Not to be hindered" (1 Peter 3:7).

St. John Chrysostom stated that God created the woman as a help for man as a supplement to it: "God wanted to help Adam with somebody like him, that He had told us above: "Let's make him help like him "; And the text read now says, "There was no help like him"; that is why God is helping him out of the substance of Adam"27.

St. Basil the Great said that man was not perfect through male sex but also by feminine, because God created man, man and woman from the beginning:

"Because no one, by ignorance, takes over the expression man only for male sex, Scripture added: Male and female parts created them. The woman also possesses, like the man, the privilege of being created in the

${ }^{25}$ ST. CYrIL OF AlEXANDRIA, "Works, Part I, Worship and servce in light and Truth", in PSB vol. 38, translated, introd. and noticed by Dumitru Stăniloae, Bucureşti, Institutul Biblic şi de Misiune al Bisericii Ortodoxe Române, 1991, p. 12.

26 Paul Evdochimov, The woman and the salvation of the world, translated by Gabriela Moldoveanu, Bucureşti, Christiana, 1995, p. 32-33.

${ }^{27}$ ST. John Chrysostom, "Works, part I, Homilies at the Creation (I)", in PSB, vol. 21, trad., introd. by Dumitru Fecioru, Bucureşti, Institutul Biblic şi de Misiune al Bisericii Ortodoxe Române, 1987, p. 168. 
image of God. Similarly, their two natures are worthy of honor, equal to their virtues, equal reward, and like punishment. The woman not to say: I'm weak! Weakness belongs to the body; in the soul is the force"28.

After the incarnation of the Lord, man has Christ as the supreme icon of creation, and man in communion with others and through love can come to union with divinity.

\section{Conclusion}

By uniformizing genres, the human person can be destroyed, immorality can be lifted to the rank of modus vivendi, and egalitarian ideology limits the person, subjecting people to some false socio-cultural and economic inequalities.

At a time when modern science denies biblical anthropogenesis, considering man to be a caged animal in the sphere of biological science and to be led to liberation only by his ideological deconstruction, by denying divine purposes, communion with God, love for neighbor, contact with the Church, the foundation Family.

Gender ideology is a failure of postmodern thinking that denies humanism and God in an attempt to turn man into a divine androgyn who tends to carnal immortality. Within this ideology, the monogamous family and women's motherhood are an obstacle which has to be removed by polygamy, polyandry, transgenderism, etc. Through the division of labor equal to that of the man, it is intended to reject the woman within the family and to dissipate it. The ultimate goal of gender ideology is to annihilate the maternal sentiment by releasing the woman from a false oppression, but abducting her freedom from within the family.

The family, as a blessed institution of God, calls upon the person to assume the mystical union with Christ, to communion and sacrifice, to open to the neighbor, to multiply the Trinitarian mystery.

\section{References}

1. *** Principles from Yogykarta, translated by Adrian R. Coman, Iustina

28 SAINT BASIL THE GREAT, "Works, part I, Homilies at Hexaemeron, Homilies at Psalms, Homilies and word", in $P S B$, vol. 17, translated, introduction by Dumitru Fecioru, Bucureşti, Institutul Biblic şi de Misiune al Bisericii Ortodoxe Române, 1986, p.78. 
Ionescu, Romaniţa Iordache and Mona Nicoară, s.1., 2009.

2. ENGELS, Friedrich, Der Ursprung der Familie, des Privateigenthums und des Staats. Im anschlu $\beta$ an Lewis H. Morgans Forschungen, Hottingen-Zürich, 1884.

3. EvDOCHIMOV, Paul, Woman and the salvation of the world, translated by Gabriela Moldoveanu, Bucureşti, Christiana, 1995.

4. Delamont, Sara, Feminist Sociology, London, Sage Publications, 2003.

5. GAGNON, John H. / Simon, William, Sexual conduct: the social origins of human sexuality, Aldine, Chicago, 1973.

6. GENNEP, Arnold van, Rites of passing, translated by Lucia Berdan and Nora Vasilescu, Iaşi, Polirom, 1996.

7. HonISCH, Pascal, Kindsein 2.0: Die Konstruktion von Kidults anhand der Phänomene des E-Gaming und Hello-Kitty-Konsums, Hamburg, 2014.

8. HorKHEIMER, Max, Studien über Autorität und Familie, Frankfurt, 1987

9. KuBY, Gabriele, Gender, A new ideology destroys the family, translated by Alexandru Ş. Bologa, Iaşi, Sapientia Publishing House, 2014.

10. KUBY, Gabriele, The global sexual revolution. Destruction of freedom in the name of freedom, translated by dr. biol. Alexandru Ş. Bologa, Iaşi, Sapientia, 2014.

11. PalaZZAni, Laura, Gender in Philosophy and Law, London, Springer, 2012.

12. Platon, "Timaios", 90a, in Opere VII, translated by Petru Creţia and Cătălin Partenie, Bucureşti, Ştiinţifică Publishing House, 1993.

13. Money, J./TuCKer, P., Sexual Signatures. On being a Man or a Woman, London-Toronto, 1975.

14. Money, J. Gay, Straight, and In-Between: The Sexology of Erotic Orientation, New York -Oxford, Oxford University Press, 1988.

15. SAINT CYRIL OF AlEXANDRIA, "Works, Part I, Worship and service in light and Truth", in PSB collection 38, trad., introd. and notices by Dumitru Stăniloae, Bucureşti, Institutul Biblic şi de Misiune al Bisericii Ortodoxe Române, 1991.

16. SAINT GREGORY OF NYSSA, Homilies of happiness, translated by Sandu Stoica, Bucureşti, Anastasia, 1999.

17. SAINT John Chrysostom, Work, part I, Homilies at Creation (I)", in PSB 21 collection, trad., introd., notices by Dumitru Fecioru, Bucureşti, Institutul Biblic şi de Misiune al Bisericii Ortodoxe Române, 1987.

18. SAINT BASIL THE GREAT, "Work, part I, Homilies at Hexaemeron, 
Homilies at Psalms, Homilies and Words”, in PSB collection, mvol. 17, translatedand notices by Dumitru Fecioru, Bucureşti, Institutul Biblic şi de Misiune al Bisericii Ortodoxe Române, 1986.

19. STOLLER, R. J., "Gender-role change in intersexed patients", in JAMA, nr. 188/1964.

20. WINKLER, Martina, Kindheit als Kategorie. Adultismus im Zusammenspiel mit anderen Herrschaftsverhältnissen, Bremen, 2015. 